\title{
PENGAMBILAN KEPUTUSAN UNTUK MEMAKAI NARKOBA PADA DEWASA AWAL YANG PERNAH MENEMPUH PENDIDIKAN DI PONDOK PESANTREN
}

\author{
KurrotaAini \& Anna Armeini Rangkuti, M.Si \\ Psikologi, Fakultas Ilmu Pendidikan, Universitas Negeri Jakarta \\ Jl. Rawamangun Muka, Jakarta Timur
}

Kurrota.aini92@gmail.com

\begin{abstract}
This study aims to determine the background factors of decision making to use drugs on young adult ever studied in boarding school.The approach used in this study is a qualitative approach with a qualitative case study approach. Subjects in this study amounted to 2 drug user after graduate from boarding school and from different boarding school, one from traditional boarding school and one from modern boarding school, they are 23 years old. Data collection techniques used were interviews. Data were analyzed using qualitative data analysis techniques and techniques of data validity checks using triangulation. These results indicatethatthere are sixfactors thataffect the subjectinmaking decisionsthatarepreferences, values, beliefs, emotions, andactioncircumstances. Of the sixfactorsarethemost influentialfactorsthatcircumstances. Environmentandthe influence of friendsis part ofcircumstancesfactorsthat affectboth subjects.
\end{abstract}

Keyword: Decision Making, Young Adult, Drugs, Boarding School

\section{Pendahuluan}

Di zaman yang serba modern seperti yang terjadi saat ini permasalahan kehidupan semakin kompleks dan beraneka ragam. Seiring dengan perkembangan zaman, modernisasi di Indonesia tidak hanya memberikan pengaruh yang positif. Banyak juga pengaruh negatif yang ditimbulkannya, salah satunya adalah timbulnya permasalahan dalam kehidupan sosial, dan permasalahan sosial yang perlu mendapatkan perhatian adalah meningkatnya kenakalan remaja dari tahun ke tahun.

Wujud dari permasalahan tersebut antara lain perkelahian, perkosaan, pencurian, membolos sekolah, seks pranikah dan juga penyalahgunaan obat terlarang atau narkoba (Poerwanto, 2001). Berdasarkan akibat yang ditimbulkannya bagi remaja, penyalahgunaan obat terlarang, baik narkoba, alkohol, maupun zat adiktif lainnya, dicatat sebagai kendala terparah dibandingkan kenakalan remaja yang lain (Hawari dalam Prasetya, 2002).Menurut Irjen Putut Eko Bayuseno selaku Kapolda Metro Jaya terjadi peningkatan pada kasus narkoba, dari 4.817 kasus di 2011 menjadi 4.836 kasus pada 2012. Kasus ini naik sebanyak 19 kasus atau 0,39 persen (www.beritasatu.com).

Narkoba adalah singkatan dari narkotika dan obat/bahan berbahaya. Selain narkoba, istilah lain yang diperkenalkan khususnya oleh
Departemen Kesehatan Republik Indonesia adalah napza yang merupakan singkatan dari Narkotika, Psikotropika dan Zat Adiktif. Semua istilah ini, baik narkoba atau napza, mengacu pada sekelompok zat yang umumnya mempunyai resiko kecanduan bagi penggunanya. Menurut pakar kesehatan narkoba sebenarnya adalah psikotropika yang biasa dipakai untuk membius pasien saat hendak dioperasi atau obat-obatan untuk penyakit tertentu. Namun kini presepsi itu disalahgunakan akibat pemakaian yang telah diluar batas dosis (Poerwanto, 2001).

Narkoba dapat menimbulkan pengaruh tertentu bagi mereka yang menggunakannya dengan cara memasukan obat tersebut ke dalam tubuhnya, hilangnya rasa sakit, semangat dan menimbulkan halusinasi. Timbulnya efek halusinansi inilah yang menyebabkan kelompok masyarakat terutama di kalangan remaja ingin menggunakan narkoba meskipun tidak menderita sakit apa-apa. Hal inilah yang mengakibatkan terjadinya penyalahgunaan narkoba (Julianan \& Nengah, 2013).

Prevalensi penyalahgunaan narkoba dalam penelitian BNN dan Puslitkes UI serta berbagai universitas negeri terkemuka, pada 2005 terdapat 1,75 persen pengguna narkoba dari jumlah penduduk di Indonesia. Prevalensi itu naik menjadi 1,99 persen dari jumlah penduduk pada 2008. Tiga 
tahun kemudian, angka sudah mencapai 2,2 persen (Kompas.com). Para pemakai narkoba tersebut rata-rata berusia muda, bahkan mereka yang terlibat banyak yang berstatus sebagai mahasiswa. Ketua Pelaksana Harian BNN, Komjen Makbul Padmanegara, mengatakan peredaran narkoba sudah sampai keseluruh wilayah di Indonesia. Dari 200 juta penduduk Indonesia, $1 \%$ atau 2 juta diantaranya positif mengkonsumsi narkoba. Diantara 2 juta penduduk Indonesia yang mengkonsumsi narkoba terdapat pelajar atau mahasiswa. Terungkap pada 2011, terdapat sebanyak 58 kasus narkotika dan obat-obatan terlarang yang di dominasi oleh mahasiswa atau pelajar. Pada tahun 2010 tercatat bahwa mayoritas pengguna narkoba adalah mahasiswa, yaitu dari 90 orang yang tertangkap 30 orang diantaranya adalah mahasiswa (Tribun Jogja.com).

Banyak faktor yang dapat menyebabkan seseorang mulai menyalahgunakan narkoba, sehingga pada akhirnya dapat menyebabkan ketergantungan. Beberapa faktor penyebab penyalahgunaan narkoba diantaranya yaitu faktor kepribadian, faktor lingkungan,faktor keluarga dan faktor pendidikan (Julianan\& Nengah, 2013).

Terkait dengan faktor kepribadian terdapat pribadi yang memiliki emosi yang belum stabil, orang yang mengalami konflik akan cenderung mengalami frustasi. Bagi individu yang tidak biasa dalam menghadapi penyelesaian masalah cenderung menggunakan narkoba, karena berpikir keliru bahwa cemas yang ditimbulkan oleh konflik individu tersebut dapat dikurangi dengan mengkonsumsi narkoba (Julianan \& Nengah, 2013).

Kasus narkoba nampaknya tak pernah berhenti. Berita mengenai seseorang yang tertangkap karena menggunakan atau menyebarluaskan narkoba nampaknya masih tetap menghiasi beberapa media di Indonesia. Dari berbagai kalangan masyarakat dapat mengkonsumsi narkoba dengan mudah, dikarenakan banyaknya pengedar narkoba yang tersebar luas di masyarakat.

Maraknya permasalahan narkoba pada zaman sekarang membuat orang tua khawatir akan masa depan anaknya.

Perlunya pendidikan karakter untuk memberikan pengetahuan mengenai bahaya penggunaan narkoba sehingga dapat mencegah penyalahgunaan narkoba. Salah satu pendidikan yang baik untuk membentuk karakter anak adalah pondok pesantren. Pendidikan pondok pesantren baik untuk membentuk karakter anak pada usia muda, karena di pondok pesantren anak tidak hanya mempelajari pengetahuan umum tetapi ditambah dengan mempelajari ilmu agama. Dalam pondok pesantren anak akan belajar hidup secara mandiri, disiplin dan mempelajari ilmu agama lebih dalam. Anak yang menetap di pondok pesantren setiap hari akan belajar menaati peraturanperaturan yang ada di dalamnya sehingga membuat anak terhindar dari masalah yang banyak terjadi di lingkungan sosial pada saat ini.

Dengan mendapatkan ilmu agama di pondok pesantren, diharapkan anak akan mempunyai pengetahuan tentang nilai-nilai hidup, lebih memahami mana perbuatan yang baik dan mana perbuatan yang tidak baik. Dengan menjalani pendidikan di pondok pesantren anak akan diajarkan ilmu agama yang menjadi nilai dasar pada hidup. Pentingnya pengetahuan tentang nilainilai hidup adalah untuk menjadikan benteng pertahanan pada diri manusia, sehingga dapat terhindar dari pengaruh yang tidak baik. Berdasarkan temuan hasil penelitian, menunjukan bahwa nilai-nilai hidup sangat berpengaruh bagi manusia, nilai-nilai tersebut menjadi benteng pertahanan untuk tidak memakai narkoba (Purwandari, 2007). Nilai-nilai hidup (values) adalah keyakinan yang terdapat pada diri seseorang bahwa perilaku yang muncul merupakan eksistensi tujuan akhir dari diri dan sosial, nilai-nilai kehidupan tersebut adalah nilai agama, nilai moral, nilai sosial, nilai pribadi, nilai keindahan, nilai intelektual dan nilai ekonomi (Debats \& Bartelds, dalam Purwandari, 2007).

Nilai dasar manusia merepresentasikan kebutuhan yang universal dari eksistensi manusia, yaitu kebutuhan biologis, kebutuhan akan interaksi sosial, dan tuntutan akan berfungsinya kelompok. Ketika seseorang mempunyai nilai - nilai yang kuat maka akan relatif terhindar dari memakai narkoba, dengan demikian pendidikan di pondok pesantren yang dapat mengajarkan nilai-nilai hidup diharapkan dapat menjadikan pondasi yang kuat bagi anak untuk tidak memakai narkoba.

Ternyata, terdapat alumni pesantren yang menyalahgunakan narkoba. Seperti salahsatu mahasiswa yang pernah menjalani pendidikan di pondok pesantren di Tasikamalaya selama 3 tahun, mengaku telah memakainarkoba selama 7 tahun sejak lulus dari pesantren. Tiga tahun menjalani pendidikan di pondok pesantren ternyata tidak dapat menjadi benteng untuk memakai narkoba. Dalam wawancara, subjek menyebutkan terdapat beberapa temannya positif memakai narkoba padahal mereka adalah lulusan dari pesantren.

Mahasiswa tersebut dapat dengan mudah mendapatkan obat-obatan terlarang dari temannya yang bekerja di rumah sakit, obat tersebut merupakan obat yang tidak dijual bebas tetapi di dapat dari apotek rumah sakit tersebut. Obat tersebut seperti obat biasa yang terdapat di apotek, tetapi mempunyai zat narkotika yang cukup tinggi, biasanya obat tersebut digunakan untuk obat penenang yang seharusnya menggunakan resep dari dokter. Salah satu jenis obat tersebut adalah Diazepam, Umumnya dokter memberi obat ini untuk mengatasi kecemasan atau panik serta 
pengaruh tidur sebagai efek utamanya, misalnya Aprazolam (Julianan \& Nengah, 2013). Biasanya mereka yang mengkonsumsi obat tersebut selalu dicampur dengan zat lain seperti alkohol, mengkonsumsi dengan cara tersebut dapat berakibat fatal karena menekan sistem pusat pernafasan (Julianan \& Nengah, 2013). Penyalahgunaan obat-obatan seperti ini telah sering dilakukan oleh mahasiswa tersebut, dengan berbagai macam jenis obat sampai ganja pernah dikonsumsinya.

Berdasarkan temuan-temuan awal di lapangan tersebut, peneliti akan menggali lebih dalam mengenai faktor-faktor apa saja yang menjadi latar belakang mahasiswa tersebut mengambil keputusan untuk mengkonsumsi narkoba.

Pengambilan keputusan untuk memakai narkoba merupakan pilihan yang mempunyai resiko tinggi yang harus ditanggung, baik oleh dirinya sendiri, keluarga, maupun lingkungan. Pengambilan keputusan adalah proses menggabungkan dan memadukan informasi yang tersedia dalam rangka untuk memilih salah satu dari beberapa pilihan yang ada (Baron \& Byrne, 2000). Sedangkan menurut James A. F. Stoner, pengambilan keputusan adalah proses yang digunakan untuk memilih suatu tindakan sebagai cara pemecahan masalah (dalam Purwandari, 2007). Dapat disimpulkan bahwa pengambilan keputusan adalah suatu proses dimana terjadi penggabungan dari semua informasi yang ada dan dirasakan sesuai untuk kemudian membuat beberapa alternatif pilihan yang sesuai dengan nilai - nilai dan preferensi yang dimiliki, untuk kemudian memilih alternatif yang paling sesuai, dengan tujuan untuk memperoleh hasil yang diinginkan dan menghindari hasil yang tidak diinginkan.

Dalam penelitian ini, penulis tertarik untuk mengetahui lebih dalam mengenai faktorfaktor apa saja yang melatarbelakangi pengambilan keputusan untuk memakai narkoba pada pemakai yang pernah menjalani pendidikan di pondok pesantren. Ketertarikan penulis dilatarbelakangi oleh kenyataan bahwa adanya pemakai narkoba yang pernah memperoleh pendidikan dari pondok pesantren. Seharusnya mereka dapat tumbuh menjadi remaja yang baik dan relatif terhindar dari beragam kenakalan remaja termasuk penyalahgunaan narkoba tapi ternyata mereka malah menjadi pecandu narkoba.

\section{Metode Penelitian}

Metode penelitian yang digunakan dalam penelitian ini ialah kualitatif. Creswell (2010) menyatakan bahwa penelitian kualitatif merupakan metode-metode untuk mengeksplorasi dan memahami makna yang dianggap berasal dari masalah sosial atau kemanusiaan. Pendekatan metode penelitian kualitatif yang digunakan dalam penelitian ini ialah metode studi kasus. Alasan peneliti menggunakan metode studi kasus ialah karena fenomena yang diangkat dalam penelitian ini khusus dan unik yaitu mengenai proses pengambilan keputusanuntuk memakai narkoba pada usia dewasa awal yang pernah menjalani pendidikan di pondok pesantren. Oleh karena itu, peneliti ingin memperoleh pemahaman utuh dan terintegrasi mengenai interrelasi berbagai fakta dan dimensi dari fenomena tersebut (Poerwandari 2009).

Awalnya subjek yang terdapat dalam penelitian ini terdiri dari tiga orang, namun 1 subjek tidak bersedia. Sehingga subjek dalam penelitian ini terdiri dari dua orang. Subjek dalam penelitian ini adalah alumni pendidikan pondok pesantren yang mengkonsumsi narkoba. Alasan dipilihnya subjek ini adalah karena sesuai dengan topik penelitian yaitu faktor-faktor yang melatarbelakangi pengambilan keputusan untuk memakai narkoba pada usia dewasa awal yang pernah menempuh pendidikan di pondok pesantren. Usia dewasa awal dipilih karena pada usia ini individu sudah mulai memikirkan masa depannya, dan memikirkan tujuan jangka panjang dan masalah-masalah praktis yang berkaitan dengan tanggung jawab mereka terhadap orang lain (Santrock, 1999).

Penelitian ini dilaksanakan pada bulan Agustus sampai dengan bulan Januari dan pengambilan data mulai dilaksanakan pada bulan Nopember:Dalam penelitian ini metode pengumpulan data digunakan dengan cara observasi, wawancara dan dokumentasi.

Dalam penelitian ini, peneliti melakukan triangulasi data dan triangulasi metode. Triangulasi data yang dilakukan peneliti ialah mengambil data dari subjek penelitian dan dari orang-orang terdekat subjek. Sedangkan triangulasi metode yang dilakukan peneliti ialah mengambil data dengan wawancara.

\section{Hasil dan Diskusi}

Faktor-faktor pengambilan keputusan yang di kaji dalam penelitian ini adalah teori Kendal \& Montgomery dalam Ranyard, Crozier, dan Svenson (1997), yaitu preferences, values, beliefs, emotions, circumstances, dan actions.

Kedua subjek pada penelitian ini melewati setiap faktor tersebut, kedua subjek memiliki kesamaan dalam faktor preferensi (preference) yaitu sama-sama mengalami tekanan ketika berada di pondok pesantren. Proses ini di dukung juga dengan lingkungan yang membuat kedua subjek menjadi ikut memakai narkoba. Seperti pada subjek I (A), pergaulannya bersama teman-teman yang 
sudah mengkonsumsi narkoba terlebih dulu membuat A terbawa dan ikut mengkonsumsi narkoba. Di lingkungan subjek II (N) tinggal, banyak remaja atau pemuda yang sering mengkonsumsi narkoba. Saudara N juga banyak yang mengkonsumsi narkoba, sehingga $\mathrm{N}$ sudah mengenal narkoba sejak kecil, meskipun pertama kali $\mathrm{N}$ mencobanya ketika $\mathrm{N}$ menginjak masa remaja. $\mathrm{N}$ juga di dukung oleh teman-temannya yang sudah mengkonsumsi narkoba terlebih dulu, sehingga membuat $\mathrm{N}$ merasa ingin mengikuti teman-temannya untuk mengkonsumsi narkoba.

Menurut teori ekologi Bronfenbrenner, teman sebaya merupakan bagian dari mikrosistem remaja. Dalam teori ekologi menyatakan bahwa lingkungan memiliki pengaruh yang besar dalam perkembangan seseorang pada level mikrosistem ini hubungan dan interaksi individu dengan lingkungan terdekat disekelilingnya, termasuk teman sebaya akan sangat mempengaruhi perkembangannya (Santrock, 1999). Kedua subjek sama-sama memiliki lingkungan dan teman yang sangat berpengaruh, jika ada salah satu diantara temannya yang tidak mengkonsumsi narkoba maka akan mendapatkan perlakuan yang kurang baik dari temannya seperti di musuhi atau di ejek. Hal ini terjadi pada kedua subjek, ketika kedua subjek menolak untuk tidak mengkonsumsi narkoba terdapat ejekan atau paksan dari temannya, sehingga membuat kedua subjek merasa terpaksa dan harus mengkonsumsi narkoba untuk menghindari perlakuan yang kurang baik dari temannya.

Menurut Hurlock (1980), pengaruh teman sebaya (peer group) sangat besar selama masa remaja, dan lebih dominan pengaruhnya dibandingkan dengan pengaruh keluarga. Tinggal berada jauh dari orangtua membuat kedua subjek menjadi merasa bebas dan lebih banyak waktu bersama teman-temannya, sehingga mereka dapat melakukan banyak hal tanpa adanya aturan dan larangan dari orangtuanya.

Meskipun kedua subjek merupakan lulusan dari pondok pesantren, tetapi penerapan ilmu agama mereka tidak diterapkan pada kehidupannya sehari-hari. Subjek I (A) merasa bahwa agama tidak terlalu penting, jika sedang ingin mengkonsumsi narkoba A selalu mengabaikan pengetahuannya tentang agama yang mengharamkan narkoba. Dalam kehidupan seharihari A jarang melakukan shalat 5 waktu, sehingga A kurang mengamalkan ilmu yang telah di dapatkannya waktu di pondok pesantren. Sama seperti subjek I, subjek II (N) juga merasa bahwa agama bukan penghalang untuk mengkonsumsi narkoba. $\mathrm{N}$ mengaku dapat melakukan taubat jika sudah merasa puas untuk mengkonsumsi narkoba, $\mathrm{N}$ merasa dirinya memang tidak sempurna. Dalam faktor nilai-nilai (Values) ini pondok pesantren yang menjadi latarbelakang kedua subjek tidak menjadi penghalang kedua subjek untuk mengkonsumsi narkoba.

Dalam faktor kepercayaan (Beliefs) terdapat perbedaan di kedua subjek. Subjek I (A) membutuhkan narkoba untuk membangkitkan kepercayaan dirinya dalam bertanding bola voli. A percaya dengan mengkonsumsi narkoba stamina tubuh akan kembali fit dan kepercayaan diri meningkat, sehingga A merasa sulit untuk meninggalkan narkoba karena $\mathrm{A}$ adalah atlit bola voli. Berbeda dengan subjek II (N), N mengkonsumsi narkoba hanya untuk mencari kesenangan. $\mathrm{N}$ merasa jika mengkonsumsi narkoba akan terlihat gaul dan asik di kalangan temantemannya.

Kedua subjek sama-sama melakukan segala cara untuk mendapatkan narkoba, seperti menjual barang-barang, memakai uang sekolah atau berbohong kepada orangtua dengan alasan yang bermacam-macam. Kedua subjek rela membohongi kedua orangtuanya karena sudah tidak ada lagi cara bagaimana mendapatkan uang untuk membeli narkoba, hal ini membuat keputusan yang diambil oleh kedua subjek sudah tidak mempunyai pilihan sehingga jalan terakhir adalah berbohong kepada orangtuanya. Manurut Atwater (1983) setiap keputusan penting yang kita buat terdapat resiko di dalamnya. Ada beberapa tipe strategi pengambilan keputusan berdasarkan resiko yang diambil seperti save strategy, yaitu memilih alternatif yang memiliki kemungkinan paling besar untuk berhasil. Begitu juga dengan kedua subjek yang memilih untuk berbohong kepada orangtuanya untuk mendapatkan uang dengan cepat.

Tabel 1. Gambaran Umum Subjek

\begin{tabular}{lcc}
\hline Aspek & Subjek I & Subjek II \\
\hline Nama & A & D \\
Jenis kelamin & Laki-laki & Laki-laki \\
Usia & 23 Tahun & 23 Tahun \\
Domisili & Jawa Barat & Jawa Barat \\
Suku & Sunda & Sunda \\
Agama & Islam & Islam \\
Pendidikan & Sedang & Sedang \\
Terakhir & berkuliah & berkuliah \\
Pekerjaan & Guru SD & Marketing
\end{tabular}

Tabel 2. Deskripsi Umum Significant Person

\begin{tabular}{lccc}
\hline Aspek & Subjek I & \multicolumn{2}{c}{ Subjek II } \\
\hline Inisial & $\mathrm{H}$ & $\mathrm{AL}$ & $\mathrm{I}$ \\
$\begin{array}{l}\text { Hubungan } \\
\text { dengan } \\
\text { Subjek }\end{array}$ & $\begin{array}{c}\text { Teman } \\
\text { subjek }\end{array}$ & $\begin{array}{c}\text { Teman } \\
\text { subjek }\end{array}$ & $\begin{array}{c}\text { Teman } \\
\text { Sunjek }\end{array}$ \\
Usia & 20 & 23 & 20 \\
Pendidikan & $\begin{array}{c}\text { Sedang } \\
\text { berkuliah }\end{array}$ & S1 & $\begin{array}{c}\text { Sedang } \\
\text { berkuliah }\end{array}$
\end{tabular}




\begin{tabular}{llll}
\hline Pekerjaan & Mahasiswa & Guru & Mahasiswi \\
& & SMP & \\
\hline
\end{tabular}

\section{Kesimpulan}

Berdasarkan hasil penelitian ini maka dapat disimpulkan bahwa terdapat enam faktor yang melatarbelakangi pengambilan keputusan untuk memakai narkoba pada usia dewasa awal yang pernah menempuh pendidikan pondok pesantren yaitu preferences, values, beliefs, emotions, circumstances dan action. Dari keenam faktor tersebut terdapat satu faktor yang sangat berpengaruh yaitu circumstances. Lingkungan dan pengaruh teman merupakan bagian dari faktor circumstances yang mempengaruhi kedua subjek.

Setelah kedua subjek selesai menempuh pendidikan di pondok pesantren, mereka merasa bebas dan dapat melakukan apa saja tanpa adanya peraturan dan hukuman seperti di pondok pesantren. dengan tekanan yang kedua subjek rasakan selama di pondok pesantren akhirnya dilampiaskan dengan mengkonsumsi narkoba dan minuman beralkohol. Kedua subjek mengenal narkoba dari teman-temannya, termasuk memutuskan untuk mengkonsumsi narkoba berdasarkan ajakan dari temannya.

Lingkungan kedua subjek juga sangat mendukung untuk mengkonsumsi narkoba, berada jauh dari orangtua menjadi kesempatan kedua subjek mengkonsumsi narkoba. Meskipun kedua orangtua subjek tidak mengetahui jika kedua subjek mengkonsumsi narkoba.

Maka dapat disimpulkan bahwa circumstances adalah faktor utama yang sangat mempengaruhi pengambilan keputusan untuk mengkonsumsi narkoba. Kedua subjek memang pernah menjalani pendidikan di pondok pesantren dan memiliki pengetahuan agama yang baik, tetapi itu tidak menjamin menjadikan seseorang terhindar dari penyalahgunaan narkoba jika tidak di dukung dengan lingkungan yang baik, teman-teman yang membawa pengaruh baik, terutama dukungan dan perhatian orangtua yang sangat penting.

\section{Daftar Pustaka}

Atwater, E. (1983). Psychology of Adjusment. New Jersey: Prentice-Hall.Inc.

Baron, R. A., \& Byrne, D. (2000). Psikologi Sosial. Jakarta: Erlangga.

Bronfenbrenner, Urie. (1917). The Ecology of Human Development: experiments by nature and design. USA: Havard College

Cresswell. Jhon. W., (2010). Research Design (Qualitative, Quantitative and Mixed Method Approaches, 3rd ed. Jakarta: Pustaka Belajar.

Dhofier, Z. (1985). Tradisi Pesantren: Studi Tentang Pandangan Hidup Kyai. Jakarta: LP3ES.
Greenberg, J. S. (1999). Comprehensive Stress Management. McGraw Hill Companies.

Hawari, P. D. (1991). Penyalahgunaan Narkotika dan Zat Adiktif. Depok: UI Press.

Hurlock, E. B. (2000). Psikologi Perkembangan, Suatu Pendekatan Sepanjang Rentang Kehidupan. Jakarta: Erlangga.

Jannis, I.L, \& Mann, L. (1977). Decision Making a Psychological Analysis of Conflict, Choice \& Commitment. New York: The Free Press

Julianan, F. R \& Nengah, S. W. (2013). Narkoba, Psikotropika dan Gangguan Jiwa. Yogyakarta: Nuha Medika

Lazarus, R. S., \& Folkman, S. (1984). Stress, Appraisal, and Coping. New York: Springer.Inc.

Moleong, Lexy J. (2010). Metodologi Penelitian Kualitatif. Bandung: Rosda.

Papalia, Diane E., Old, Sally Wendkos., Feldman, Ruth Duskin. (2008). Human Development (Psikologi Perkembangan), 9th ed. Jakarta: Kencana.

Parker, Ian. (2005). Psikologi Kualitatif. Yogyakarta: Andi

Plous, Scott. (1993). The Psychology of Judgement and Decision Making. USA: McGrawHill.Inc

Poerwandari, Kristi. (2009). Pendekatan Kualitatif untuk Penelitian Perilaku Manusia. Depok: LPSP3 UI.

Poerwanto, H. (2001). Kebudayaan dan Lingkungan . Jakarta: Pustaka Pelajar.

Purwandari, E. (2007). Orientasi Nilai-nilai Hidup . Proses Pengambilan Keputusan Berhenti Mengkonsumsi NAPZA .

Ranyard, Rob \& Crozier, Ray. W. (1977). Decision Making, Cognitive Models and Explanation. New York: Routledge

Santrock, J. W. (1999). Adolesence. Jakarta: Erlangga

Smith, Jonathan A. (2009). Dasar-Dasar Psikologi Kualitatif. Bandung:Nusa Media.

Yasmadi. (2002). Modernisasi Pesantren. Jakarta: Ciputat Press.

http://jogja.tribunnews.com/2012/01/13/mahasiswa -terlibat-peredaran-narkoba-di-yogya/

http://regional.kompas.com/read/2011/03/11/18534 04/Penyalahgunaan.narkoba.meningkat.ter utama.pada.remaja

http:/www.beritasatu.com/megapolitan/89874polda-metro-kenakalan-remajameningkatpesat-perkosaan-menurun.html 